\title{
SUBCIDADANIA E MODERNIZAÇÃO DESIGUAL EM BECOS DA MEMÓRIA, DE CONCEIÇÃO EVARISTO
}

\author{
Gabriel Estides Delgado* \\ Universidade de Brasília
}

Resumo: Em uma poética descentrada, coletiva, Conceição Evaristo narra as agruras do processo brasileiro de modernização excludente diretamente tributário da clivagem escravagista que ultrapassa a Abolição em 1888. Sob forte especulação do capital, travestido em ímpeto urbanizador (dir-se-ia "sanitário"), vê-se o desmonte de uma favela, situada em zona nobre e central, de Belo Horizonte. A figuração coletiva que emerge em Becos da memória aponta para as transformações modernas da dominação, que deixa de ser direta e pessoal e passa à eficácia, como se racionalmente fundamentada, de seu exercício liberal. Para uma análise que situe os expedientes formais utilizados por Evaristo dentro da série literária contemporânea, serão abordadas algumas características da produção fíccional de Luiz Ruffato, principalmente de seu romance em fragmentos Eles eram muitos cavalos. A comparação busca apontar continuidades e diferenças nos projetos de representação das classes populares empreendidos pelos autores. Caso a análise logre êxito, as escolhas formais destacadas devem iluminar em si a diversidade de encaminhamentos poéticos possíveis ao tratamento de tão exigente dinâmica referencial.

Palavras-chave: Becos da memória. Conceição Evaristo. Literatura afro-brasileira contemporânea. Literatura brasileira contemporânea.

\section{Introdução}

Becos da memória, romance de Conceição Evaristo (2006), escrito ainda na década de 1980 (EVARISTO, 2006, p. 9), narra as agruras de uma comunidade sob duplo signo de exclusão. O primeiro, a exposição à miséria, faz-se acompanhar por um ímpeto urbanizador que deve expulsar as personagens de seu espaço historicamente habitado. O plano de desfavelização, política pública incensada por um mercado em franco desenvolvimento, apresenta-se como modelo, de investigação simbólica, das muitas erradicações de moradias que ousam ocupar espaços centrais das grandes cidades brasileiras, muitas vezes, como ocorre

EY No ND Esta obra está licenciada sob uma Licença Creative Commons.

\footnotetext{
* Doutorando em Literatura na Universidade de Brasília (UnB). Programa de Pós-Graduação em Literatura. Departamento de Teoria Literária e Literaturas. Integrante do Grupo de Estudos em Literatura Brasileira Contemporânea (CNPq/UnB). Bolsista CAPES. E-mail: gabrielestides@gmail.com.
} 
no romance de Evaristo, vizinhos, a poucos minutos de distância, dos bairros nobres onde está a oferta de trabalho.

Evaristo, como se verá, utiliza-se de sua experiência pessoal para transpor literariamente os dramas que sua protagonista, Maria-Nova, observa na comunidade da qual é parte. A percepção do fundamento coletivo de seu sofrimento, além de representar a redenção política e espiritual de Maria-Nova, que se vê lançada para fora de si, com a capacidade crítica ampliada, é princípio formal que rege a composição de Becos da memória. O processo formativo de Maria-Nova, e, como seu duplo implícito, a condição de escritora negra de Conceição Evaristo, forja-se no contato aberto e receptivo com as tantas personagens que acusam, de diferentes modos, a espoliação histórica e institucionalmente ancorada de suas vidas. Tem-se desse modo, um mosaico de existências breves, refletido em diversas frentes de relato, que deve compor, de maneira plural e, com efeito, fraturada, um quadro condensado das consequências da modernização pela qual passou o país a partir do movimento abolicionista.

Como lembra Luiz Costa Lima (1981, p. 127), a "via específica" da ficção pavimenta-se como "exploração simbólica das instituições sociais e de suas repercussões no universo simbólico dos indivíduos". Desse modo, descortina-se "o que não seria apreensível pela análise direta destas instituições, que a respeito limita-se a apresentar estatísticas e testemunhos ilustrativos.” O problema poético no qual nossa análise pretende se deter, isto é, as escolhas de fundo formal que norteiam o trabalho de Evaristo, pauta-se, desse modo, pelo desvelamento de trajetórias precarizadas por diversas das modulações do regime social que rompe o século XX no Brasil sob mantras modernizantes liberais, produzindo nefasta seletividade na ordem do trabalho e consequente exclusão da população negra. São histórias apagadas seja pela inépcia e insipidez dos relatos escolares, seja pela perspectiva autoral branca, que, não sendo interna à experiência negra, projeta muitas vezes na representação literária dos excluídos neuroses e fobias sociais caras a grupos preservados, expressas, por exemplo, na violência gratuita de várias composições de nosso cânone contemporâneo ${ }^{1}$.

Para um caminho que reponha a obra de Evaristo na tradição recente de figuração das classes populares, é, portanto, necessário desvinculá-la de início de tal pasteurização da

\footnotetext{
${ }^{1}$ Pensamos, aqui, com Regina Dalcastagnè (Cf. 2012), na poética de um Dalton Trevisan, ou nas obras de Rubem Fonseca. Essa marca fóbica de nossas letras é lembrada também por Eduardo de Assis Duarte (2006) em apresentação a Becos da memória, na qual opõe a característica ao livro ora analisado. Tal aspecto, no entanto, não poderá ser desenvolvido a contento nesta oportunidade.
}

Anu. Lit., Florianópolis, v. 20, n. 1, p. 15-31, 2015. ISSNe 2175-7917 
alteridade que determinada estética a que chamamos fóbica acaba por causar ${ }^{2}$. Desse modo, afigura-nos como base coerente de comparação, no cotejamento de prolongamentos e também de diferenças, o romance Eles eram muitos cavalos, de Luiz Ruffato (2013 [2001]). Procurouse demonstrar que, ponto até então culminante da obra de Ruffato, esse livro em fragmentos, como se retalhado, estabelece profícuas relações com Becos da memória, sobretudo quando divergem na condução narrativa de seus exigentes painéis romanescos.

\section{A Abolição como "ironia atroz" - o caso de Eles eram muitos cavalos}

Em "Degradação e acumulação: considerações sobre algumas obras de Luiz Ruffato", Andrea Saad Hossne (2007) procura identificar, na poética que dá origem ao ciclo de figuração proletária forjado pelo escritor mineiro, norteamentos formais que possibilitam a representação consequente dos desdobramentos modernos da luta de classes no Brasil. O impacto mimético da obra de Ruffato estaria na capacidade de transposição, com poder de ressonância artística, dos encadeamentos sociais tributários da feição particular que a industrialização e a urbanização acabaram por tomar entre nós. Para dar conta dos novos padrões de sociabilidade, em que a dominação assume outras formas, muitas vezes difusas e impessoais, o escritor, no trabalho poético que culmina em Eles eram muitos cavalos (2013 [2001]), assume, por acúmulo dos expurgos e excessos ruidosos do sistema produtivo urbano, a condição contemporânea da organização do trabalho nas cidades; condição, sabe-se, pósindustrial $^{3}$ e potencialmente desagregadora. Suas personagens, em radical precariedade, compõem a paisagem ruinosa de um processo modernizador que tem por base a distribuição desigual dos recursos. A lógica fragmentária e sucessiva dos diversos enredos desenvolvidos em sua obra ficcional ${ }^{4}$ parece indicar a impossibilidade de construção retilínea e coerente de histórias e projetos de vida. Particularmente em Eles eram muitos cavalos, as muitas personagens aglutinam-se numa massa comprimida desdobrada do perímetro urbano (no caso, São Paulo). São breves e espasmódicos laivos de vida que se entreveem cruzando-se pela cidade. Mesmo a parcela inserida no mercado de trabalho, com a tranquilidade da renda

\footnotetext{
2 Estorvo, romance de estreia de Chico Buarque (2004 [1991]), igualmente pauta-se por representação amedrontada das classes baixas, sobre as quais recai a paranoia do narrador.

${ }^{3}$ É preciso atentar para a contínua automatização da produção industrial. Se até o último quarto do século passado, as indústrias, em sua maior parte automobilísticas, eram as principais responsáveis pela geração de postos de trabalho, seja no Brasil, junto com a construção civil, seja, por exemplo, nos Estados Unidos, é cada vez maior a importância do setor terciário na ocupação e renda da classe trabalhadora. (Cf. Singer, 2012, p. 2528).

${ }^{4}$ Cf., sobretudo, os cinco volumes de Inferno provisório (2005a; 2005b; 2006; 2008; 2011), bem como os dois livros de contos que, reescritos e rearranjados, deram origem à série - Histórias de remorsos e rancores (1998) e (os sobreviventes) (2000).
}

Anu. Lit., Florianópolis, v. 20, n. 1, p. 15-31, 2015. ISSNe 2175-7917 
garantida, revela-se em crise, também atingida pelo regurgitar sem sentido de uma maquinaria cuja seletividade produz violência. Mas essa minoria ${ }^{5}$, composta sobretudo, em Eles eram muitos cavalos, por uma classe média bem intencionada e bem pensante, nos termos de Hossne, de onde derivaria a perspectiva engajada da narração, só é definida a partir da relação que estabelece com um contingente populacional mais numeroso, marcado pela exclusão do mercado de trabalho, consequência inevitável de um despreparo global que segue abastecido.

Para André Singer (2012, p. 20-21), “a singularidade das classes no Brasil consiste no peso do subproletariado, cuja origem se deve procurar na escravidão, que ao longo do século XX não consegue incorporar-se à condição proletária, reproduzindo massa miserável permanente". Do constrangimento físico e moral herdado, infligido diretamente, por meio do mando e do confinamento, seguiu-se a condição precária de inserção em novo contexto institucional, como nota Jessé Souza (2003, p. 154-155):

O dado essencial de todo processo de desagregação da ordem servil e senhorial foi
[...] o abandono do liberto à própria sorte [...]. Os antigos senhores, na sua imensa
maioria, o Estado, a Igreja ou qualquer outra instituição, jamais se interessaram pelo
destino do liberto. Este, imediatamente depois da aboliçãa, se viu responsável por si
e por seus familiares, sem que dispusesse dos meios materiais ou morais para
sobreviver numa nascente economia competitiva do tipo capitalista e burguês. Ao
negro, fora do contexto tradicional, restava o deslocamento social na nova ordem.
Ele não apresentava os pressupostos sociais e psicossociais que são os motivos
últimos do sucesso no meio ambiente concorrencial [...]. Neste contexto, [...] estava
$[\ldots]$ prefigurado o destino da marginalidade social e da pobreza econômica.

Narrativas, pois, que examinem e pretendam refletir internamente o dilema nacional, deparar-se-ão com a continuidade histórica da desigualdade e a reprodução como se automática das condições que a originam. No entanto, motriz ideológico da Abolição, é necessário atentar para o ímpeto liberal modernizador que importou e, ao importar, desenhou as modernas instituições nacionais. Para Jessé Souza (2003, p. 134), “a sociedade colonial, localista, provinciana e baseada em relações pessoais, experimenta por assim dizer um 'choque cultural' que a transforma, paulatina mas radicalmente, em uma sociedade nacional com relações de dominação crescentemente impessoais". Tal movimento, porém, vem sendo sinalizado desde os inícios do século XIX, com "a lenta decadência da cultura patriarcal rural [...] a partir do desenvolvimento das cidades e da cultura urbana" (SOUZA, 2003, p. 137). A chegada da família real em 1808 aumenta o peso do Estado na vida da colônia; data também do mesmo ano a abertura dos portos comerciais, antes monopolizados pela metrópole. Souza

\footnotetext{
5 "Recorda-se que $56 \%$ da população brasileira não usufrui de acesso ao esgotamento sanitário, e segundo o IBGE, em 2008, 43\% das moradias deveriam ser consideradas inadequadas, por ausência de coleta de lixo, de abastecimento de água, de esgotamento por rede coletora ou fossa séptica, ou por terem mais de dois moradores por quarto" (SINGER, 2012, p. 129-130).
} 
enxerga aqui a ilustração mais visível das origens (ou da inserção) do capitalismo moderno tal qual conhecido hoje no Brasil. Afinal, naquele ponto estabeleciam-se as "duas práticas institucionais mais fundamentais e importantes do mundo moderno: Estado e mercado" (SOUZA, 2003, p. 137):

Se aqui a mercantilização crescente da vida econômica passa a ameaçar os fundamentos estamentais da base socioeconômica do patriarcalismo, a entrada do Estado e de seus agentes, ainda que ambiguamente e sob o peso de compromissos constantes, completa o quadro de substituição paulatina e capilar do poder pessoal e familiar pelas instituições impessoais recém-importadas (SOUZA, 2003, p. 138).

O ciclo modernizador na periferia acompanha e reage às mudanças nos modelos centrais, sofrendo a influência de uma Europa já francamente burguesa. O rompimento com o estatuto colonial vai dinamizar as relações e a doutrina liberal "irá se transformar [...] no ideário mais adequado para a expressão da visão de mundo e dos interesses da nova sociedade que se formava a partir das entranhas e da lenta decadência da antiga" (SOUZA, 2003, p. 133). A premência de uma reorganização nacional, direcionada segundo os interesses da nova economia de mercado, no entanto, é incapaz de fugir aos contornos mesquinhos de um acordo entre elites, "que torna a Abolição uma 'revolução social de brancos para brancos', [...] inaugurando, daí, um abandono secular de uma 'ralé' despreparada para enfrentar as novas condições socioeconômicas" (SOUZA, 2003, p. 133).

Em A integração do negro na sociedade de classes, estudo clássico relido por Souza, Florestan Fernandes alerta para a condição problemática do movimento abolicionista:

\begin{abstract}
A revolução abolicionista, apesar de seu sentido e conteúdo humanitários, fermentou, amadureceu e eclodiu como um processo histórico de condenação do "antigo regime" em termos de interesses econômicos, valores sociais e ideais políticos da "raça dominante". A participação do negro no processo revolucionário chegou a ser atuante, intensa e decisiva, principalmente a partir da fase em que a luta contra a escravidão assumiu feição especificamente abolicionista. Mas, pela própria natureza da sua condição, não passava de uma espécie de aríete, usado como massa de percussão pelos brancos que combatiam o "antigo regime" (FERNANDES, 2008 [1964], p. 30).
\end{abstract}

Para Fernandes ${ }^{6}$, o modelo de reorganização do trabalho que se operava, reprodutor da violenta clivagem social da ordem escravocrata, estava determinado por sua estrutura econômica, alheia, sob novos signos liberais e competitivos, à sorte do ex-escravo. Em suma, "a cena histórica era insensível a reinvindicações que não terminavam com 'a liberdade da pessoa humana', mas iam além dela, exigindo-a como mera condição preliminar" (FERNANDES, 2008 [1964], p. 30).

\footnotetext{
${ }^{6}$ Cf. capítulo um, “O negro na emergência da sociedade de classes” (FERNANDES, 2008 [1964], p. 29-117).
} 
A estrutura e a dinâmica da economia brasileira não impunham às camadas dominantes outra orientação. Nas zonas onde a prosperidade econômica desparecera, [...] a Abolição era uma dádiva: livravam-se de obrigações onerosas ou incômodas [...]. Nas zonas onde a prosperidade era garantida pela exploração do café, existiam dois caminhos para corrigir a crise [...]. Onde a produção se encontrava em níveis baixos, os quadros da ordem tradicionalista se mantinham intocáveis: como os antigos libertos, os ex-escravos tinham que optar [...] entre a reabsorção no sistema de produção, em condições [...] análogas às anteriores, e a degradação de sua situação econômica, incorporando-se à massa de desocupados e de semi-ocupados da economia de subsistência do lugar ou de outra região. Onde a produção atingia níveis altos, refletindo-se no padrão de crescimento econômico e de organização do trabalho, existiam reais possibilidade de criar um autêntico mercado de trabalho (FERNANDES, 2008 [1964], p. 31).

As vagas geradas eram, porém, refratárias à absorção dos ex-escravos, dada a concorrência desleal com os chamados "trabalhadores nacionais", mantidos, até então, "fora de atividades produtivas, em regiões prósperas, em virtude da degradação do trabalho escravo". Mas havia, sobretudo, a mão-de-obra importada da Europa, "com frequência constituída por trabalhadores mais afeitos ao novo regime de trabalho e às suas implicações econômicas ou sociais" (FERNANDES, 2008 [1964], p. 31).

Nas teses de Souza (2000 e 2003), corroboradas por Singer (2012), o racismo estrutural brasileiro fundamenta-se, e segue condicionado de modo circular, na precariedade histórica do habitus de parte majoritária da população negra. Disruptiva e improdutiva em relação aos caracteres melhor premiados (recompensados) pela moderna economia competitiva, a personalidade "negra"7, sobredeterminada pela distribuição desigual de recursos (muitas vezes escassos), é relegada à humilhação "à margem da sociedade incluída" 8 (SOUZA, 2003, p. 160).

Entre as repercussões centrais da, nos termos de Rui Barbosa (apud FERNANDES, 2008 [1964], p. 29), “ironia atroz” na qual a Abolição se convertera, está a desagregação familiar derivada da espoliação extrema e cruel a que o liberto seguiu sendo submetido. $\mathrm{Na}$ tradução literária e contemporânea de Eles eram muitos cavalos, esse ponto dá-se a ver sobretudo na brevidade das biografias esboçadas. Não há lastro genealógico possível a vidas não integradas ao sistema produtivo da megalópole. Desse modo, imersões narrativas no tempo, que não sofrem a concorrência tirânica da necessidade, e, portanto, do presente, seguem como característica usual apenas na representação de grupos preservados, como se

\footnotetext{
${ }^{7}$ Souza apoia-se no supracitado estudo de Fernandes (2008 [1964]), em que o autor, além de tratar dos condicionantes sócio-históricos do malogro da reabsorção da mão-de-obra liberta, empreende exaustiva radiografia da identidade negra deslocada em relação à nova ordem competitiva. Para uma análise abreviada sobre tal inadequação ou falta de tecnologia concernente ao mercado de trabalho liberal, cf., do autor (2007 [1972]), O negro no mundo dos brancos.

8 "Ora, é precisamente o abandono secular do negro e do dependente de qualquer cor à própria sorte a 'causa' óbvia de sua inadaptação. Foi este abandono que criou condições perversas de eternização de um 'habitus precário' que constrange esses grupos a uma vida marginal e humilhante" (SOUZA, 2003, p. 160).
} 
melancolicamente voltados à própria sombra. Em Eles eram muitos cavalos, a falta de estruturação de disposições psicossociais que permitam a sobrevivência pacificada em meio ao inchaço demográfico (que, por sua vez, reabastece a pauperização e anomia), atinge, contudo, a totalidade do tecido social, como bem pode-se notar nos fragmentos dedicados a personagens ricas que também cruzam a cidade, seja em bólidos possantes (fragmento 4, p. 14-15), seja em helicópteros (fragmento 16, p. 34); reféns da má consciência de classe, manifestada não raro pelo ódio racial, são vítimas sobretudo da própria condição, possível apenas se complementar à miséria.

O ímpeto figurativo de Ruffato, que visa capturar um instantâneo da trama urbana de nossa maior cidade, corre o risco, por outro lado, de anular as existências representadas. O traço marcadamente fatalista de sua poética nunca é maior do que quando, ao invés de vidas narradas em movimento, o discurso urbano supra-individual de São Paulo (poder-se-ia pensar em qualquer outra grande cidade) se autonomiza a ponto de transcender em importância as personagens, indicando certa suficiência e circularidade de ideologemas - o "texto" da cidade - ao longo de gerações que não seriam mais do que seus veículos.

Essa indiferença altiva da História perante seus agentes diminuídos é pregada em diversos fragmentos, desde a hagiologia (RUFFATO, 2013[2001], p. 13) que compõe a abertura da narrativa, passando por outros ready-made, catados ao acaso entre os impressos da urbe, como o horóscopo (RUFFATO, 2013 [2001], p. 28), a "oração a Santo Expedito" (RUFFATO, 2013 [2001], p. 57-58), ou o pletórico cardápio (RUFFATO, 2013 [2001], p. 124-125 $)$ que figura entre as últimas páginas da trama. O ponto máximo, entretanto, de anulação do sujeito pela miríade discursiva que vai constituí-lo a partir de injunções de classe, é a heterogênea e parca estante de livros (RUFFATO, 2013 [2001], p. 46-47 ${ }^{10}$ ) apresentada por inteiro e isoladamente ao leitor, como se índice de gerações obstadas pelos limites da formação escolar. Deriva, pois, em certa superioridade do compilador de fragmentos em relação à matéria compilada. O escritor, tal qual o intelectual, surge, reiterando uma característica já notada por Pierre Bourdieu (1996 [1992], p. 49-50), como observador privilegiado, ou melhor, "criador incriado". A reflexão e o distanciamento necessários ao

\footnotetext{
9 “ENTRADA/ Salada de aspargo fresca com medalhão de lagostas e endívias [...]/ Ovas de salmão [...]/ PRATO PRINCIPAL/ Risoto de endívia com presunto cruzeiro/ SOBREMESA [...]/ Sorvete de creme e maracujá com cúpula de caramelo $[\ldots . .$. ".

10 "HITLER - Joachim Fest/ MARKETING BÁSICO - Marcos Cobra/ O VERMELHO E O NEGRO Stendhal/ O PREÇO DA GUERRA - Hans Killian/ AS AVENTURAS DE SHERLOCK HOLMES - Conan Doyle/ AS VALKÍRIAS - Paulo Coelho/ BRASIL POTÊNCIA FRUSTRADA - Limeira Tejo/ TEREZA BATISTA CANSADA DE GUERRA - Jorge Amado [...]/ O HOMEM À PROCURA DE SI MESMO - Rollo May/ CURSO TÉCNICO EM TRANSAÇÕES IMOBILIÁRIAS - João da Silva Araújo/ A ERA DO GELO Margaret Drabble/ NOS DOMÍNIOS DA MEDIUNIDADE - Francisco Cândido Xavier".
}

Anu. Lit., Florianópolis, v. 20, n. 1, p. 15-31, 2015. ISSNe 2175-7917 
trabalho formal são, desse modo, eficaz maneira de "arrancar-se a todas as determinações e sobrevoar em pensamento o mundo social e os seus conflitos".

\section{Becos da memória}

O descentramento e a rarefação das vidas traçadas por Ruffato encontram raro paralelo em Becos da memória, romance de Conceição Evaristo de inspiração autobiográfica. O livro, entretanto, é marcado por uma perspectiva de narração horizontal, mais generosa, posto que ligada diretamente às personagens. Ainda fugazes e em essência frágeis, desvelam um padrão de tratamento formal que é diferente ao de Eles eram muitos cavalos, sendo que as frações de classe tratadas permanecem as mesmas. Se há, na representação paulistana de Ruffato, ganhos de complexidade na interpretação e entendimento por meio da autonomização da língua, que, em seu sedimento histórico-discursivo, antes de ser instrumentalizada, captura, ela mesma, os indivíduos - é a esta anulação das possibilidades de agência que Ruffato quer sublinhar -, tal empreendimento, cerebral e autorreferente, acaba por servir mais a um diálogo intracampo, rendendo graças à tradição de questionamento linguístico-textual, que segue refém de seu problema agigantado. Outros caminhos são percorridos por Conceição Evaristo em Becos da memória. A narrativa, também estruturada em fragmentos, não os traz, no entanto, numerados, à moda de Eles eram... e suas 70 seções. No caso da representação paulistana, a numeração é parte do efeito de acumulação de discursos socialmente determinados que se impõem por somatória aos habitantes da cidade. Becos... apresenta um mosaico de vidas representadas igualmente de maneira breve, presas à urgência de seu presente e a um passado em grande parte das vezes desconhecido, dada a violência da desagregação social que rompeu o século XX estilhaçando laços estáveis, sejam familiares ou comunitários. Mas, ao contrário do amálgama textual que acachapa e funde as personagens de Ruffato em um, apesar de polifônico, único e intransigente sedimento discursivo - malgrado o engajamento político da obra -, tem-se em Becos a prevalência de perspectiva arejada e em formação, de sua personagem principal.

Maria-Nova, jovem de 13 anos, moradora da favela do Pindura Saia (BARBOSA, 2006), situada em zona central e nobre da Belo Horizonte dos anos 1950, 1960 (EVARISTO, 2006, p. 40), confunde-se com a narradora do romance. Escrita em terceira pessoa, em diversos momentos a trama é assumida pela personagem a partir de uma sintomática e fraterna primeira pessoa do plural. O efeito é de sobreposição entre narradora e protagonista, uma vez que a mudança de condução narrativa é feita de modo sutil, em períodos subsequentes. O modo fragmentário de composição serve-se, repetindo os motivos de Eles 
eram..., de lógica cumulativa, em que as muitas frentes do relato são possíveis apenas em conjunto. Há, porém, uma solda afetiva e espacial que difere da representação paulistana. Se o efeito, em Ruffato, pauta-se pela caoticidade de cruzamentos discursivos capazes apenas de reificação, em Becos acompanha-se um processo formativo, transposto da experiência da autora, que confere sentido e unidade à matéria observada.

A heterogeneidade e descontinuidade das experiências apreendidas pela personagem são mantidas e acusadas formalmente pela obra. Mas, ao invés do imobilismo e do alheamento entrevistos, por exemplo, em Eles eram..., na enunciação enumerativa de objetos que definem personagens (Cf., por exemplo, fragmento 32, "Uma copa""11), o corte biográfico da narrativa de Evaristo preserva a autonomia crítica e participativa da personagem frente aos condicionamentos tão flagrantes e sensíveis.

Logo de início, compondo as várias e efêmeras frentes de narração, separadas de modo fragmentar, surgem as personagens mais próximas a Maria-Nova. Maria-Velha, a tia materna; Tio Totó, marido de Maria-Velha; Joana, sua mãe. Tal núcleo de relações irá dar origem a outras tantas histórias, das quais sobressaem-se as ouvidas de Totó e Maria-Velha. Avós por adoção, esse casal destaca-se pela memória de uma vida já ampla e repleta de perdas. Ao contrário da enigmática e fechada Mãe Joana, compartilham suas trajetórias.

Maria-Velha, mulher dura [...], era a terceira mulher de Tio Totó. Quando encontrou o homem, ela também já tinha uma larga e longa coleção de pedras [...]. MariaVelha e Tio Totó ficavam trocando histórias, permutando as pedras da coleção [...]. As pedras pontiagudas que os dois colecionavam eram expostas à Maria-Nova, que escolhia as mais dilacerantes (EVARISTO, 2006, p. 33).

A disposição da escuta leva ao contato com a dispersão familiar sofrida pelas duas personagens. Filho de escravos, Totó é obrigado a sair da fazenda em que fora criado. Já sem os pais, vitimados pela tuberculose, relata a perda, em circunstâncias trágicas - na travessia precipitada de um rio transbordante - da primeira mulher e da filha (EVARISTO, 2006, p. 25). À solidão e aos trabalhos sazonais de colheita em diferentes propriedades segue-se o segundo casamento. Nega Tuína, órfã de mãe escrava, sem parentes sanguíneos (EVARISTO, 2006, p. 52), acompanha Totó em direção à cidade.

Vinha sabendo onde iria ficar. Um amigo estava esperando por ele. Tinha dinheiro suficiente que dava para comprar um barraco. Iria aprender uma profissão. Aprenderia a fazer casas de tijolos. Na roça sabia fazer casa de pau-a-pique. Aqui na capital carece da gente aprender tudo, da gente aprender um novo modo de viver...

[...]. Quando cheguei à favela, ainda existia muito lugar vazio. Esta minha casa era

\footnotetext{
11 “[U]m álbum de fotografias, Alpes Suíços/ uma bíblia tradução João Ferreira de Almeida/ dois vasos de flores de plástico idênticos/ dois vasos de flores desidratadas [...]/ 1 videocassete Panasonic NV-SD 435/ 1 aparelho de televisão Semivox/ 4 tulipas de chope Kaiser [...]" (RUFFATO, 2013 [2001], p. 59-60).
}

Anu. Lit., Florianópolis, v. 20, n. 1, p. 15-31, 2015. ISSNe 2175-7917 
só um quartinho, fui aumentando aos poucos. Hoje, você vê, menina, são quatro cômodos; comecei aqui com Nega Tuína (EVARISTO, 2006, p. 84).

Ali, sob condições de pauperização extrema, perde a segunda mulher, morta ao dar à luz a gêmeos. Simultaneamente, em fragmentos interpostos desenrolam-se outras frentes de narração. São histórias passadas na favela. Premidas, como dito, pela necessidade, estão atidas de modo inapelável ao presente. Os parcos recuos a uma história pretérita e, mesmo assim, plena de lacunas, devem-se, sobretudo, às lembranças amargas de Totó e à sua terceira esposa, Maria-Velha. A partir do relato da tia, Maria-Nova entra em contato com o universo dispersante de suas origens maternas. O silêncio altivo e intimidante de Mãe Joana - "MariaNova nunca conseguira uma história de Mãe Joana, embora ela tivesse tantas" (EVARISTO, 2006, p. 42) - encontra respaldo nos cortantes dramas que marcam há muito a família. À invalidez física da mãe de Joana e Maria-Velha ${ }^{12}$ junta-se o enlouquecimento progressivo do pai de ambas, Luisão da Serra, narrado a Maria-Nova a começar da tristeza irreparável de seu bisavô, pai de Luisão.

Dos vários filhos que tivera, perdera quase todos. Vivo, só tinha Luisão e, mesmo assim, louco [...]. Quando venderam a sua irmã, por ela ter agarrado o sinhô pelo peito da camisa, ele vomitava ódio e prometia se vingar, pôr fogo na casa-grande. Chorou a noite inteira. E o pai teve uma surpresa. Luís falou com ele durante horas naquela língua da terra distante. $O$ pai pensava que o garoto soubesse falar só a linguagem dos brancos. Qual nada! (EVARISTO, 2006, p. 37).

De modo relacional ao círculo íntimo de Maria-Nova, outras tantas experiências vêm à tona. São personagens que frequentam a casa de Totó ou simplesmente compõem o imaginário da favela. Entre as mais expressivas, destacam-se mulheres autônomas, que sustentam e criam sozinhas seus filhos. No próprio caso de Maria-Nova, em nenhum momento tem-se referida a figura do pai. A matrifocalidade da trama acompanha a configuração genérica das famílias brasileiras negras e pobres. Tal situação, derivada historicamente, entre outros condicionantes, do "quase monopólio dos serviços domésticos, única área onde a competição com o imigrante não era significativa" (SOUZA, 2003, p. 157), passa longe de ser resolução pacificada para a organização social que se conforma. Ainda que de algum modo tenham mais facilidade no acesso ao mercado de trabalho, se comparativamente à dificuldade de inserção do homem negro, são capturadas pela especificidade espoliativa desse mercado, que não se faz acompanhar por garantias sociais mínimas.

\footnotetext{
12 “A mãe cuidava um pouco da casa, tinha um lado esquecido. Torrou café, saiu na friagem, pegou vento, diziam” (EVARISTO, 2006, p. 33).
} 
É o caso, por exemplo, de Ditinha, uma das vizinhas de Maria-Nova. Mãe solteira de três filhos, é responsável ainda por cuidar da irmã mais jovem, que acaba por prostituir-se, e do pai, idoso e paralítico. Sua renda advém da faxina em casa rica do bairro nobre próximo e é, com efeito, insuficiente para que Ditinha se mude com sua família da favela. Exemplo potente das muitas oposições perversamente complementares que Evaristo alimenta ao longo do romance, a história dessa empregada doméstica em crise aumenta a lucidez de Maria-Nova na sua busca por discernimento sensível da vida.

\begin{abstract}
Ditinha estava cansada, humilhada. Olhou seu barraco, uma sujeira. As roupas amontoadas pelos cantos. Olhou as paredes, teias de aranha e picumãs. Um cheiro forte vinha da fossa. Era preciso jogar um pouco de cal virgem sobre as bostas. Esperou as crianças um pouco mais. Não chegaram. Tirou o pai da cadeira de rodas e colocou na cama. O pai fedia a sujeira e cachaça. Lembrou-se da patroa tão limpa e tão linda com as joias. Pensou que o dia de amanhã seria duro. A casa estaria de pernas para o ar depois da festa. (EVARISTO, 2006, p. 96-97).
\end{abstract}

$\mathrm{Na}$ disposição das mulheres que referenciam o mundo de Maria-Nova, a remuneração subumana do trabalho braçal faz-se acompanhar por violência doméstica e péssimas condições sanitárias. O primeiro caso, sabe-se, alastrado pela sociedade como um todo, independentemente de classe social, é figurado, na sua condição mais extrema, por Fuizinha e sua mãe. Maria-Nova compadece-se com a vizinha de idade próxima a sua, oprimida e abusada sexualmente pelo pai, que a impede de travar relações, mantendo-a confinada. A rotina de espancamentos da qual a mãe de Fuizinha é vítima acaba por ceifar sua vida.

Dispôs da vida da mulher até à morte. Agora dispunha da vida da filha. Só que a filha, ele queria bem viva, bem ardente. Era o dono, o macho, mulher é para isto mesmo. Mulher é para tudo, mulher é para apanhar, mulher é para gozar, assim pensava ele. O Fuinha era tarado (EVARISTO, 2006, p. 76).

Há também o caso de Custódia. Convivendo com o alcoolismo do marido, sua maior algoz, entretanto, é a sogra. Mal disfarçado pelo fervor religioso - tem sempre a Bíblia à mão -, o ódio de Dona Santina volta-se contra a nora. "Custódia divisava somente o livro, aquele ponto preto ali na sua frente. Dentro da Bíblia estava escrito assim: 'E tu, mulher, parirás em dores!' O ventre dela doía. Havia parido, alguns dias antes, seu bebê de quase sete meses. Parido entre dores e à força." (EVARISTO, 2006, p. 78).

Vítima de uma surra da sogra e da inépcia do companheiro, a solidão a que vê-se Custódia submetida é mais um dos quadros a compor a paisagem devastadora da infância de Maria-Nova. A ele, soma-se o afeto a mulheres vitimadas pelas más condições sanitárias de moradia do morro em que se relacionam. Um dos casos exemplares é o de Vó Rita, antiga 
parteira da favela. Modelo amoroso da protagonista, Vó Rita tem o "coração grande" (EVARISTO, 2006, p. 31). A metáfora, que encontra eco na profunda gratidão de MariaNova e de todos que conviveram com a personagem, se, por um lado, representa o valor de relações sobretudo dignas e humanas, mesmo que expostas à miséria, por outro, não escapa à cruel sugestão. Vó Rita, como tantas outras, é chagásica. Há também outro "mal” a separá-la dos que a muito estimaram, confiando-lhe o parto de seus filhos. Já na velhice junta-se a uma companheira, nomeada na narrativa como "a Outra", o que levará Maria-Nova a questionamentos fundamentais. À dificuldade de todos na favela em conviver com a lesbianidade do casal, que acaba, por si só, em segregar Vó Rita, conjuga-se o Mal de Hansen da "Outra". "Vó Rita dormia embolada com ela. E quando eu via Vó Rita, minha curiosidade ardia. Eu olhava para Vó Rita de cima a baixo. Procurava alguma marca, algum vestígio da Outra em seu rosto, em seu corpo. Nem uma marca, nem um sinal.” (EVARISTO, 2006, p. 30). A condição radical de alteridade dessa personagem mostra-se importante para a construção de todos os outros momentos da trama. É que o caminho de decifração da realidade empreendido por Maria-Nova só se torna literariamente possível a partir do confronto com estigmas que, de outro modo, impediriam a protagonista de entrar em contato sensível e construtivo com as muitas vidas que a cercam. A insistência em aproximar-se da "Outra", sua necessidade de aproximação, fornece uma das melhores definições para a narrativa futuramente urdida por Conceição Evaristo. "Uma sombra se movimentou e quando o enigmático corpo percebeu os olhos da menina em cima de si, ela se desfez [...]. O pior era aquela menina, com seu olhar curioso, cruel, desesperado. Aquela busca incessante." (EVARISTO, 2006, p. 44).

De maneira igualmente nefasta, a tuberculose impõe sacrifícios à favela. Ligada em proporção direta à falta de estrutura sanitária, assim como o mal de Chagas, o mal de Hansen e tantas outras lástimas que acompanham, conformam e reproduzem a disposição de classes no Brasil, a tuberculose vitima Filó Gazogênia, uma das colegas de Mãe Joana na lavação de roupas. A filha e a neta de Filó, moradoras do mesmo barraco e também doentes, têm melhor sorte e conseguem, por intermédio do patrão da filha, ser internadas a tempo.

O sangue escorria pela boca de Filó Gazogênia e o peito arfava... 'Deus meus, eu não quero ir assim, tão sozinha!' Como estariam a filha e a neta? Filó Gazogênia, num esforço imenso, ameaçou abrir os olhos. Pensou, entretanto, que seria melhor continuar com eles fechados. Abrir os olhos para quê? Ela já conhecia de cor o seu barraco. Duas camas: a dela e a da filha, que dormia junto com a neta. No cantinho, o fogão de lenha e a prateleira de madeira onde estavam as latas de mantimentos vazias, as louças velhas, as canequinhas de latas e as duas panelas, uma de ferro e outra de barro. Durante toda a doença, uma das latas vazia, a de 'gordura de côco carioca', ficava ali parada, olhando para ela. A cada um que chegava, ela desejava 
pedir que tirasse a lata dali. Calava, depois pensariam que ela, além de tuberculosa, estivesse doida. De olhos fechados, viu a lata de 'gordura de côco carioca' e teve ódio, muito ódio. (EVARISTO, 2006, p. 100).

Com espanto, Maria-Nova acompanha os estertores daquela mulher tão parecida com Tio Totó e Maria-Velha. Percebe a simetria que ata a sua trajetória juvenil a destinos como esse. Não pode desviar o olhar.

Lá estava Maria-Nova de olhos, ouvidos e coração bem abertos [...]. O peito estava a arrebentar de dor. Deus meu, Filó Gazogênia morria! Tantos outros haviam morrido também. Sentia medo, muito medo. Dos outros becos da favela, as pessoas iam aparecendo pouco a pouco. (EVARISTO, 2006, p. 104).

Companheira de serviço de Maria-Velha e Mãe Joana, Filó deixa como espólio seu instrumento de trabalho junto à torneira pública. Como em um espelhamento da resistência que motiva a composição de Becos da memória, tem-se o zelo e a homenagem das amigas à lavadeira, lutando pela manutenção memorialística de sua existência.

Maria-Nova ali olhava a tina que fora antes de Filó Gazogênia. Ela começava a
rachar ao sol. As lavadeiras procuravam jogar sobre ela as águas usadas, procuravam
mantê-la cheia. Ela resistiu por algum tempo, mas agora um câncer bravo estava a
comer-lhe a madeira. O ponto de ligação entre uma tábua e outra apresentava fendas
[...] visivelmente abertas, mesmo que lhe apertassem o arco. (EVARISTO, 2006, p.
149-150).

A metáfora da tina carcomida, assim como os outros relatos de dor exemplificados, que impõem lutos particulares, aponta, porém, para a crise de desfavelização pela qual passa o grupo. A usurpação de seu espaço - ocupado pelos primeiros moradores há mais de cinquenta anos (EVARISTO, 2006, p. 69) -, há de fender as ligações conquistadas pela comunidade a duras penas. A galeria de indivíduos pobres, subempregados ou criminosos ${ }^{13}$ que povoa o romance, como se não bastasse a precariedade anterior de sua condição, paga o preço de tal política e a crise vivida pelo grupo é a matéria privilegiada por Maria-Nova. A narração, como dito, colada à perspectiva da protagonista, investiga e é motivada pelas repercussões individuais da desfavelização, disparadas pela contenda espacial que enreda a comunidade. A pressão imobiliária, ancorada institucionalmente, seja pelo governo, seja pela justiça, vai produzir desde moradores de rua (EVARISTO, 2006, p. $158^{14}$ ) a falecimentos de idosos que se recusam a migrar para a periferia, como no caso de Tio Totó (EVARISTO, 2006, p. 160).

\footnotetext{
${ }^{13}$ Ver, por exemplo, a história de Bondade (EVARISTO, 2006, p. 39).

14 "Tivemos notadamente três ou quatro semanas de trégua enquanto as últimas famílias que haviam ficado recebiam a notificação de retirada. Foi um tempo sem valia, a não ser de aumentar a nossa dor. Todo mundo já havia definido para onde iria. Mesmo aqueles que iriam para lugar algum. Houve pessoas que assumiram oficialmente a mendicância e foram morar na rua."
} 
O plano de desfavelamento [...] aborrecia e confundia a todos. Havia um ano que a coisa estava acontecendo. A favela era grande e haveria de durar muito mais. Dava a impressão de que nem eles sabiam direito por que estavam erradicando a favela. Diziam que era para construir um hospital ou uma companhia de gás, um grande clube, talvez [...]. De tempos em tempos, apareciam por lá engenheiros para medir a área. Não se sabia se os pretensos donos seriam de uma companhia particular ou se gente do Governo. Vinha o medo. E quando o plano de desfavelamento aconteceu na prática é que fomos descobrir que os pretensos donos éramos nós. (EVARISTO, 2006, p. 108-109).

O poder econômico institucionaliza-se por meio de garantias legais a sua expansão, inacessíveis à parcela espoliada. É que há naturalização da desigualdade, como pressuposto da diferença real entre indivíduos, como lembra de modo oportuno Jessé Souza (2003). Tal concepção, veiculada diuturnamente pelos meios de comunicação e pela publicidade, recorre, nas sociedades liberais contemporâneas, a certa "ideologia do desempenho" (SOUZA, 2003, p. 168), que premeia, como características inatas, predicados de racionalidade produtiva que só dependeriam de esforço ou adequação individuais. Os êxitos excepcionais de carreiras de superação provariam a neutralidade eletiva do mercado, o que deve amparar moralmente a distribuição desigual de recursos e serviços. Com isso, as condições de possibilidade de tais inclusões ou êxitos tornam-se opacas aos sujeitos, que reproduzem os valores de dominação de modo espontâneo e pré-reflexivo ${ }^{15}$. O consenso, sustentado por parte significativa da classe trabalhadora não organizada, e que abastece as usurpações legalmente fundamentadas, é de valor diferencial entre os sujeitos e baseia-se sobretudo em uma " "tríade meritocrática' que envolve qualificação, posição e salário", sendo que a qualificação, como reflexo da extraordinária importância do conhecimento para o desenvolvimento do capitalismo, "é o primeiro e mais importante ponto que condiciona os outros dois" (SOUZA, 2003, p. 169). Nesse sentido, é particularmente relevante a representação da escola pública em Becos da memória. Sem perder de vista que a narrativa se passa em meados do século passado, no período que corresponde à pré-adolescência da autora, observa-se o deslocamento de MariaNova no espaço escolar. Uma das duas únicas estudantes negras de sua sala, ela relata:

As crianças maiores acordavam cedo [...], trazendo nos olhos e no estômago a
desesperada expectativa. Será que hoje tem pão? Os menores, os nenéns brigando
com a vida, dando socos no ar exigindo o peito da mãe ou a mamadeira completada
com mais água, sempre. Algumas crianças se levantavam e tomavam o rumo da
escola. Poucos, muito poucos, iam todos os dias. A escola os inibia. Bom, na escola,
era a merenda que a gente comia. (EVARISTO, 2006, p. 153-154).

As inúmeras histórias e personagens através das quais Maria-Nova dá notícia de seu espanto e dor - "A menina crescia. Crescia violentamente por dentro. Era magra e esguia.

\footnotetext{
${ }^{15}$ Para David Harvey, uma das características marcantes do neoliberalismo é fazer a vítima se sentir culpada por seu fracasso. Conferência proferida em 19 de novembro de 2014 no Centro Cultural São Paulo.
} 
Seus ossinhos do ombro ameaçavam furar o vestidinho gasto. Maria-Nova estava sendo forjada a ferro e fogo" (EVARISTO, 2006, p. 72-73) - consolidam experiências estranhas à prática escolar. Tal descontinuidade só robusteceria o alheamento e a precarização de grupos subalternos, e vai sugerir à autora o caminho de ruptura pela escrita literária.

Na semana anterior, a matéria estudada em História fora a 'Libertação dos Escravos' [...]. Fitou a única colega negra da sala e lá estava a Maria Esmeralda entregue à apatia. Tentou falar [...]. Pensou em Tio Totó. Isto era o que a professora chamava de homem livre? [...]. Pensou em Nega Tuína, em Filó Gazogênia, em Ditinha. Pensou em Vó Rita, na Outra e em Bondade [...]. Era diferente de ler aquele texto. Assentou-se e, pela primeira vez, veio-lhe um pensamento: quem sabe escreveria esta história um dia? Quem sabe passaria para o papel o que estava escrito, cravado e gravado no seu corpo, na sua alma, na sua mente. (EVARISTO, 2006, p. 137-138).

Tal intento só é tornado possível por uma poética descentrada, coletiva, que recolhe da vizinhança, de sua constelação afetiva, motivos de figuração, isto é, elaboração dos excessos que assomam violentamente à consciência juvenil da observadora. Ainda que o eixo crítico, e, nesse caso, de unificação das múltiplas experiências reunidas em distintos fragmentos, seja Maria-Nova (o que deve, como mencionado, impedir que obra se renda a qualquer tipo de fatalismo - no caso de Eles eram muitos cavalos, fatalismo linguístico -), o critério de construção dessa personagem, que firma-se a cada página, progressivamente, está nas dores alheias, que a precedem e ultrapassam. A percepção do fundamento coletivo de sua existência aguça a curiosidade e a necessidade de elaboração. Surgem, daí, retalhos de vidas que compõem o painel, como se "amontoado" (EVARISTO, 2006, p. 21), do livro.

\section{Conclusão}

Atenta à condição do grupo que investiga ficcionalmente, Conceição Evaristo diz em espécie de prólogo de Becos da memória, em que se antevê o empenho de seu ofício, do “desejo dolorido de escrever" (EVARISTO, 2006, p. 20) a motivar-lhe. O ponto de vista interno às experiências transpostas é, com efeito, condição formal das escolhas de sua prosa, mas não define por si só os caminhos a serem seguidos. Os ganhos que procuramos apontar dizem respeito à maneira pela qual a escritora lidou com matéria tão íntima. Ainda que se trate de processo formativo, que privilegia a integração problemática da protagonista ao mundo que se descortina, tal busca narrada em Becos da memória, que é, como visto, a própria busca por inclusão do negro na sociedade de classes, em momento algum dobra ou hipertrofia a interioridade de Maria-Nova, a partir da qual deriva a narração. Desse modo, a alteridade das múltiplas personagens construídas por Evaristo é preservada como tal. Tem-se quase a impressão de que a protagonista sai de cena: o duro amadurecimento percorrido não 
compete com as existências observadas. Não há risco de convertê-las a mera projeção de "si". Não que a organicidade entre instância autoral e frações de classe representadas pudesse por si mesma impedir tal projeção deformante; mas, uma vez estabelecida a poética descentrada de Becos..., sua abertura sensível e constitutiva, a representação de indivíduos precarizados não passa pelas fantasias, entre a fatalidade e o paternalismo, que a luta de classes acaba por gerar nas elites culturais bem intencionadas.

\section{Referências}

BARBOSA, Daniel. Lembranças do morro do Pindura Saia. O Tempo Magazine, Belo Horizonte, 6 jun. 2006.2 Disponível http://www.otempo.com.br/diversão/magazine/lembranças-do-morro-do-pindura-saia1.323964. Acesso em: 21 nov. 2014.

BOURDIEU, Pierre. As regras da arte: gênese e estrutura do campo literário. Trad. Miguel Serras Pereira. Lisboa: Editorial Presença, 1996 (1992).

BUARQUE, Chico. Estorvo. 2.ed. São Paulo: Companhia das Letras, 2004 (1991).

DALCASTAGNÈ, Regina. Literatura brasileira contemporânea: um território contestado. Vinhedo: Horizonte; Rio de Janeiro: Uerj, 2012.

DUARTE, Eduardo de Assis. Apresentação (“orelha") a EVARISTO, Conceição. Becos da memória. Belo Horizonte: Mazza, 2006.

EVARISTO, Conceição. Becos da memória. Belo Horizonte: Mazza, 2006.

FERNANDES, Florestan. O negro no mundo dos brancos. 2.ed. São Paulo: Global, 2007 (1972).

A integração do negro na sociedade de classes: (o legado da "raça branca"), v. 1. 5. ed. São Paulo: Globo, 2008 (1964).

HOSSNE, Andrea Saad. Degradação e acumulação: considerações sobre algumas obras de Luiz Ruffato. In: HARRISON, Marguerite Itamar (Org.). Uma cidade em camadas: ensaios sobre o romance Eles eram muitos cavalos, de Luiz Ruffato. Vinhedo: Horizonte, 2007, p. 1842 .

LIMA, Luiz Costa. Réquiem para a aquarela do Brasil. In: Dispersa demanda: ensaios sobre literatura e teoria. Rio de Janeiro: Francisco Alves, 1981, p. 124-143.

RUFFATO, Luiz. Histórias de remorsos e rancores. São Paulo: Boitempo, 1998. . (os sobreviventes). São Paulo: Boitempo, 2000. . Mamma, son tanto felice, v. 1 do Inferno provisório. Rio de Janeiro: Record, 2005a. . O mundo inimigo, vol. 2 do Inferno provisório. Rio de Janeiro: Record, 2005b. 
. Vista parcial da noite, vol. 3 do Inferno provisório. Rio de Janeiro: Record, 2006.

2008.

. O livro das impossibilidades, vol. 4 do Inferno provisório. Rio de Janeiro: Record,

. Domingos sem Deus, vol. 5 do Inferno provisório. Rio de Janeiro: Record, 2011.

. Eles eram muitos cavalos. 11.ed. São Paulo: Companhia das Letras, 2013 (2001).

SINGER, André. Os sentidos do lulismo: reforma gradual e pacto conservador. São Paulo: Companhia das Letras, 2012.

SOUZA, Jessé. A modernização seletiva: uma reinterpretação do dilema brasileiro. Brasília: UnB, 2000.

A construção social da subcidadania: para uma sociologia política da modernidade periférica. Belo Horizonte: UFMG; Rio de Janeiro: IUPERJ, 2003.

[Recebido em fevereiro de 2015 e aceito para publicação em junho de 2015]

Sub-citizenship and unequal modernization in Conceição Evaristo's Becos da memória

Abstract: In a decentered and collective poetic, Conceição Evaristo narrates the bitterness of exclusionary Brazilian modernization process, directly linked to slavery cleavage that exceeds the Slavery Abolition (1888). Under strong capital speculation, configured in urbanizing impulse (understood as "sanitary"), we see a shantytown dismantling occurring in a central high-value area of Belo Horizonte. The collective figuration that emerges in Becos da memória points to the modern transformation of domination, which is no longer personal and direct, and passes to the effectiveness of its liberal exercise, an efficacy that appears to be rationally justified. To analyze the formal arrangements used by Evaristo in contemporary literary scene, this article will discuss some fictional production characteristics of Luiz Ruffato, especially his novel in fragments Eles eram muitos cavalos. The comparative analysis purpose seeks to show continuities and differences in the working classes representation of the projects undertaken by these authors. In the case that the analysis is successful, the formal choices that were outlined should themselves highlight the diversity in the range of possible poetic directions when dealing with such demanding referential dynamics.

Keywords: Becos da memória. Conceição Evaristo. Afro-Brazilian contemporary literature. Contemporary Brazilian literature.

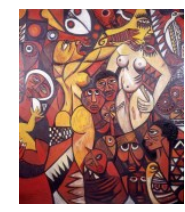

